\title{
Pengaruh Model Pembelajaran Word Square Berbantuan Media Gambar terhadap Hasil Belajar IPA
}

\author{
${ }^{*}$ I Gusti Agung Dodi Adnyana1, I Gede Margunayasa², Nyoman Kusmariyatni ${ }^{3}$
}

1,2,3 Jurusan Pendidikan Guru Sekolah Dasar, FIP, Universitas Pendidikan Ganesha Singaraja, Indonesia

Article history: 2018

Received in revised form 09 December 2018

Accepted 15 January 2019

Available online 25

February 2019

Kata Kunci:
word square, media
gambar.
Keywords:
word square, picture media.

A R T I C L E IN F O

Received 10 November

\begin{abstract}
A B S T R A K
Hasil belajar IPA siswa kelas V SD dengan model pembelajaran konvensional sangat rendah. Penelitian ini bertujuan untuk mengetahui pengaruh yang signifikan hasil belajar IPA antara siswa kelas V SD yang dibelajarkan menggunakan model pembelajaran Word Square berbantuan media gambar dan hasil belajar IPA siswa kelas V SD yang dibelajarkan menggunakan pembelajaran. Penelitian ini merupakan penelitian semu (quasi eksperimen) dengan rancangan non equivalent posttest only control grup design. Populasi penelitian ini adalah seluruh kelas $V$ yang berjumlah 190 siswa. Sampel pada penelitian ini adalah kelas $\mathrm{V}$ berjumlah 28 siswa dan kelas V berjumlah 26 siswa. Sampel ditentukan menggunakan teknik random sampling. Data hasil belajar dikumpulkan menggunakan tes pilihan ganda. Data yang diperoleh dianalisis menggunakan teknik analisis statistik deskriptif dan analisis statistik inferensial yaitu uji-t. Hasil penelitian menunjukkan bahwa terdapat pengaruh hasil belajar IPA antara kelompok siswa yang
\end{abstract} dibelajarkan menggunakan model pembelajaran Word Square berbantuan media gambar dan kelompok siswa yang dibelajarkan menggunakan model pembelajaran konvensional pada siswa kelas V SD. Hal ini ditunjukkan oleh thitung $(9,143)>$ ttabel $(2,021)$. Selanjutnya, rata-rata (mean) kelompok eksperimen $(19,96)$ lebih besar daripada rata-rata (mean) kelompok kontrol $(15)$. Dengan demikian, model pembelajaran Word Square berbantuan media gambar berpengaruh signifikan terhadap hasil belajar IPA siswa kelas V SD.

\begin{abstract}
A B S T R A C T
The aims of this study is to determine the significant result differences in learning IPA(science) between groups of students who are thought using learning model type Word Square using piccture as a medium with group of students who are taught using conventional learning model. This research is quasi-experiment, with non equivalent posttest only control group design. The population of this research is the primary school students of grade V Gugus VII Seririt Subdistric which is amounted to 190 student. 28 students of grade $V$ in were the sample of this study and was determined using random sampling technique. Learning result data is collected using multiple choice test. Statistical descriptive analysis technique and statistical inferential analysis namely t-test were used in analyzing the collected data. The results of study shows that there were differences of the result in learning IPA (science) between groups of students who were thought using learning model type Word Square using picture as a medium with group of students who were taught using conventional learning model in fifth grade students of $S D$ Subdistric. This is shown by $t$-count $(9,143)>t$-table $(2.021)$. Furthermore, the average of experimental group (19.96) was bigger than the control group average (15). Thus, learning model type Word Square with picture as a medium have a positive effect on the result in learning IPA (science) of students in grade Vt Subdistric of the academic year 2017/2018.
\end{abstract}

Copyright (C) Universitas Pendidikan Ganesha. All rights reserved. 


\section{Pendahuluan}

Di zaman sekarang proses pembelajaran yang diharapkan adalah pembelajaran yang mampu meningkatkan keaktifan dan kebermaknaan pada siswa. Pembelajaran tidak hanya berpatokan kepada asumsi-asumsi ataupun pendapat dari pendidik saja, tetapi pembelajaran yang juga mengambil dari sudut pandang peserta didik. Harapan dari pembelajaran tersebut adalah siswa menemukan dan menyampaikan masalah dari berbagai sumber dan sudut pandang, selanjutnya guru mengkonfirmasi dan menuntun siswa untuk menemukan jalan keluar masalah tersebut agar potensi-potensi yang dimiliki peserta didik dapat diketahui dan dikembangkan oleh pendidik. Namun pembelajaran yang mengembangkan potensi siswa harus sesuai dengan prinsip-prinsip belajar yang benar.

Prinsip-prinsip belajar yang dikemukakan tersebut diharapkan mampu menuntun guru agar lebih memahami kebutuhan peserta didik demi mencapai tujuan pembelajaran secara maksimal. Dengan memahami secara penuh prinsip-prinsip belajar dalam proses pembelajaran maka guru senantiasa akan memahami apa yang dibutuhkan oleh siswa.Prinsip belajar merujuk kepada hal-hal penting yang harus dilakukan guru agar terjadi proses belajar mengajar yang membuat siswa berperan aktif. Dalam proses pembelajaran hal terpenting yang dilakukan oleh guru adalah memfokuskan pandangan serta pemikiran siswa pada materi yang diberikan sehingga siswa tahu apa materi yang belum dimengerti ataupun yang sudah dimengerti. Harapannya ketika siswa tahu apa yang tidak dimengerti maka siswa berani menunjukan sikap kritis dan aktif dalam bertanya. Dalam mengajar guru harus pandai menggunakan pendekatan secara arif dan bijaksana, bukan sembarangan yang bisa merugikan anak didik. Pandangan guru terhadap anak didik juga menentukan sikap dan perbuatan. Setiap guru tidak selalu mempunyai pandangan yang sama dalam menilai anak didik. Hal ini akan mempengaruhi pendekatan yang guru ambil dalam pengajaran (Djamarah \& Zain, 2002). Sama halnya dengan guru, tidak semua peserta didik mempunyai bakat dan kemampuan yang sama. Laju perkembangan bakat, minat dan selera peserta didik berbeda-beda (Rooijakkers, 1991). Peran guru sangatlah penting dalam proses pembelajaran, tidak hanya menyelenggarakan kegiatan pembelajaran maupun bertindak mengajar dan membelajarkan tetapi juga harus mampu membuat suasana pembelajaran yang menyenangkan sesuai dengan materi dan mata pelajaran yang disajikan.

Menurut Pindo \& Simbolon(2018) IPA merupakan mata pelajaran yang sangat penting untuk dipelajari di tingkat SD, sebab membahas tentang peristiwaperistiwa yang terjadi di alam dan dekat dengan kehidupan peserta didik tersebut. Pendidikan IPA di sekolah dasar juga diharapkan dapat menjadi wahana peserta didik untuk mempelajari diri sendiri dan alam sekitar, serta prospek pengembangan lebih lanjut dalam menerapkannya di kehidupan sehari-hari. Proses pembelajaran IPA harus menekankan pada pemberian pengalaman secara langsung oleh peserta didik untuk mengembangkan kompetensi agar menjelajahi dan memahami alam sekitar, yang pada akhirnya mereka menemukan sendiri konsep materi pelajaran yang sedang dipelajarinya. Mata pelajaran IPA merupakan salah satu diantara beberapa mata pelajaran yang diterima di sekolah dasar. IPA adalah suatu kumpulan teori yang sistematis, penerapannya secara umum terbatas pada gejala-gejala alam, lahir dan berkembang melalui metode ilmiah seperti observasi dan eksperimen serta menuntut sikap ilmiah seperti rasa ingin tahu, terbuka, jujur, dan sebagainya (Trianto, 2012). Namun kenyataannya guru belum sepenuhnya bisa menciptakan suasana pada saat pembelajaran yang mampu meningkatkan sikap ilmiah seperti rasa ingin tahu, terbuka, jujur, berpikir kritis dan sebagainya. Sehingga mata pelajaran ini dianggap sulit oleh sebagian peserta didik, mulai dari jenjang sekolah dasar sampai sekolah menengah. Hal tersebut didukung data yang dihasilkan pada saat observasi di Gugus VII Kecamatan Seririt. Dari tujuh sekolah dasar di gugus VII yang telah diobservasi, diambil enam sekolah dasar yang menerapkan Kurikulum Tingkat Satuan Pendidikan (KTSP) untuk diukur persentase ketuntasan hasil belajar IPA siswanya. Dari hasil hitungan, perolehan persentase ketuntasan hasil belajar IPA siswa kelas V SD Gugus VII Kecamatan Seririt masih rendah.

Para guru belum sepenuhnya melaksanakan pembelajaran secara aktif dan kreatif dalam melibatkan siswa serta belum menggunakan berbagai pendekatan, metode maupun strategi pembelajaran yang bervariasi berdasarkan karakteristik materi pelajaran, seperti memadukan media dengan suatu model atau strategi pembelajaran. Melalui hasil wawancara juga menunjukan guru dalam proses pembelajaran lebih dominan menggunakan metode ceramah, hal ini membuat siswa merasa jenuh dalam pembelajaran dan pada saat proses belajar mengajar, kebanyakan guru hanya berpatokan pada buku teks sebagai satu-satunya sumber mengajar. Keadaan semacam ini yang membuat kegiatan pembelajaran hanya terpusat pada penyampaian materi dalam buku teks sehingga menyebabkan hasil belajar siswa belum banyak mencapai KKM.

Menyikapi permasalahan di atas, perlu diupayakan usaha dari guru agar memiliki semangat yang tinggi untuk memperluas pemahaman tentang bagaimana menyajikan suatu pembelajaran dalam bentuk baru. Sebagai salah satu caranya adalah guru harus bisa membangkitkan siswa dalam pembelajaran 
tersebut. Guru bisa mengubah model atau metode yang membuat siswa aktif dalam proses pembelajaran tersebut tepatnya dengan menerapkan pembelajaran yang inovatif. Pembelajaran inovatif yang disukai oleh siswa biasanya pembelajaran yang meningkatkan rasa penasaran siswa tersebut sehingga rasa ingin tahunya meningkat dan membuat waktu terasa singkat dalam proses pembelajaran tersebut. Salah satu bentuk pembelajaran inovatif adalah pembelajaran dengan model pembelajaran Word Square. Penambahan suatu media dalam penerapan model pembelajaran Word Square ini juga akan membuat pembelajaran lebih menarik. Media gambar sangat cocok digunakan dalam model ini karena akan lebih memfokuskan siswa dalam proses pembelajaran(Widiartini, 2014). Penerapan sebuah model yang digabungkan dengan suatu media diharapkan mampu membuat siswa aktif serta fokus terhadap materi pembelajaran untuk meningkatkan hasil belajar siswa. Sama halnya dengan penerapan model Word Square ini diharapkan mampu mampu membuat siswa aktif, kreatif, dan memiliki motivasi belajar yang tinggi. Untuk lebih jelasnya mengenai pengertian model pembelajaran Word Square yang diharapkan mampu meningkatkan hasil belajar siswa berikut akan dijelaskan sedikit model tersebut. Hasni (2017) model pembelajaran Word Square merupakan model pengembangan dari metode ceramah yang diperkaya dan berorientasi kepada keaktifan peserta didik dalam pembelajaran. Menurut Hermandannu (2018) model pembelajaran Word Square merupakan model yang bertujuan untuk melatih ketelitian dan kritis dalam menentukan jawaban. Menurut Putri (2017) model pembelajaran Word Square termasuk salah satu model pembelajaran yang memudahkan guru serta siswa dalam penerapannya ketika proses pembelajarannya. Selain itu, tidak terlalu banyak memotong waktu yang sudah ditentukan. Penggunaan model pembelajaran Word Square mampu memberikan hasil belajar siswa yang lebih maksimal dibandingkan dengan model-model pembelajaran yang lain.

Penggunaan model pembelajaran ini di kelas diharapkan juga mengurangi ketergantungan siswa terhadap guru sehingga pembelajaran tidak hanya berpusat pada guru. Model pembelajaran Word Square ini akan mampu meningkatkan hasil belajar siswa(Sukandheni, Suadnyana, \& Putra, 2014). Lestari (2013) juga menyatakan hasil belajar siswa yang mengikuti pembelajaran menggunakan Model Pembelajaran Word Square berada pada kategori tinggi sehingga model pembelajaran ini bagus untuk meningkatkan hasil belajar IPA siswa. Dengan hanya menerapkan model pembelajaran saja belum tentu mampu meningkatkan hasil belajar siswa oleh karena itu dalam proses pembelajaran, guru juga memerlukan suatu media untuk memvisualkan konsep yang ada di buku ajar. Media pembelajaran akan membantu meningkatkan hasil pembelajaran IPA, namun media yang diberikan haruslah sesuai dengan model pembelajaran yang terapkan. Media pembelajaran akan lebih membantu pemahaman siswa terhadap materi yang diberikan apalagi media yang mampu memvisualisasikan imajinasi siswa(Dimyati;Mudjiono, 2009). Media berupa gambar adalah salah satu media yang mampu memvisualisasikan imajinasi siswa. Media gambar adalah perwujudan lambang dari hasil peniruan-peniruan benda-benda, pemandangan, curahan pikiran atau ide-ide yang divisualisasikan ke dalam bentuk dua dimensi dan dapat dimengerti serta dinikmati dimana-mana. Sifatnya yang konkret, membuat media gambar lebih realistis untuk menyampaikan imajinasi siswa (Kurniasari, 2013). Media gambar dapat mengatasi batas ruang dan waktu. Tidak semua benda, objek atau peristiwa dapat dibawa ke kelas, dan tidak selalu bisa anak-anak dibawa ke objek atau peristiwa tersebut. Media gambar akan dapat menambah semangat siswa dalam mengikuti proses pembelajaran dan dapat meningkatkan hasil belajar mata pelajaran IPA siswa.

Hasil temuan penelitian pada penelitian ini memiliki persamaan dengan penelitian yang relevan sebelumnya dan memperkuat hasil penelitian yang diperoleh. Didukung oleh hasil penelitian Swapranata, Riastini, \& Japa (2016) yang menyimpulkan bahwa penerapan model pembelajaran word square dapat meningkatkan hasil belajar IPA siswa kelas V semester genap di SD Negeri 1 Tista Tahun Pelajaran 2015/2016.Berdasarkan uraian diatas, model pembelajaran Word Square dapat dijadikan alternatif untuk meningkatkan hasil belajar IPA siswa dan penting untuk diteliti pengaruh model pembelajaran Word Square berbantuan media gambar terhadap hasil belajar IPA siswa Kelas V di Gugus VII Kecamatan Seririt Tahun Pelajaran 2017/2018.

\section{Metode}

Penelitian ini bertujuan untuk pengaruh yang signifikan hasil belajar IPA antara siswa kelas V SD yang dibelajarkan menggunakan model pembelajaran Word Square berbantuan media gambar dan hasil belajar IPA siswa. Penelitian ini merupakan penelitian semu (quasi eksperimen) dengan rancangan. Penelitian ini dilaksanakan pada siswa kelas V SD yang dibelajarkan menggunakan pembelajaran konvensional di Gugus VII Kecamatan Seririt tahun pelajaran 2017/2018. Penelitian ini merupakan penelitian eksperimen. Penelitian eksperimen ini merupakan penelitian yang gejalanya secara sengaja diadakan oleh peneliti. 
Metode yang digunakan dalam penelitian ini adalah metode penelitian eksperimen yaitu suatu cara pendekatan, dimana gejala atau objek yang akan diteliti itu dibuat atau ditimbulkan secara sengaja. Penelitian ini termasuk penelitian eksperimen semu (quasi experiment) karena tidak semua variabel yang muncul dan kondisi eksperimen dapat diatur dan dikontrol secara ketat. Pada penelitian ini, variabel terikat adalah hasil belajar IPA, variabel bebas adalah model pembelajaran Word Square.. Penelitian ini mengikuti desain penelitian quasi experiment dengan rancangan non-equivalent control group design. Kelas eksperimen menerima treatment atau perlakuan berupa penggunaan model pembelajaran Word Square berbantuan media gambar sedangkan pada kelas kontrol diberlakukan pembelajaran dengan tanpa menggunakan model pembelajaran Word Square berbantuan media gambar. Dalam penelitian ini tidak semua variabel yang muncul dapat dikontrol secara ketat. Variabel yang dapat dikontrol secara ketat hanyalah pada hasil belajar antara kelompok eksperimen dan kelompok kontrol saat menganalisis hasil dari post-test.

Populasi dalam penelitian ini adalah siswa kelas V SD di Gugus VII Kecamatan Seririt Kabupaten Buleleng. Namun, dari keseluruhan SD yang ada di Gugus VII Kecamatan Seririt hanya enam sekolah yang diambil sebagai populasi hal ini dikarenakan penelitian ini hanya mengukur sekolah yang masih menggunakan Kurikulum Tingkat Satuan Pendidikan (KTSP) sedangkan dari ketujuh sekolah dasar yang ada di gugus VII Kecamatan Seririt ada satu sekolah yang sudah menggunakan Kurikulum 2013 sehingga sekolah tersebut tidak dimasukan ke dalam populasi. Adapun sebaran populasi siswa kelas V SD di Gugus VII Kecamatan Seririt, dapat dilihat pada Tabel 1.

Tabel 1. Data Siswa Kelas V SD di Gugus VII Kecamatan Seririt

\begin{tabular}{clcc}
\hline No & Nama Sekolah & Kelas & Jumlah siswa \\
\hline 1 & SD Negeri 2 Lokapaksa & V & 45 \\
2 & SD Negeri 3 Lokapaksa & V & 38 \\
3 & SD Negeri 4 Lokapaksa & V & 28 \\
4 & SD Negeri 5 Lokapaksa & V & 16 \\
5 & SD Negeri Ularan & V & 37 \\
6 & SD Negeri Umeanyar & V & 26 \\
& & Total & 191 \\
\hline
\end{tabular}

Uji kesetaraan pada penelitian ini dilakukan dengan menganalisis nilai Ulangan Akhir Semester (UAS) mata pelajaran IPA siswa kelas V SD di Gugus VII Kecamatan Seririt pada semester ganjil tahun pelajaran 2017/2018. Untuk uji kesetaraan dilakukan dengan menggunakan uji Anava satu jalur. Kriteria pengujian, jika Fhitung lebih kecil daripada Ftabel (Fhitung < Ftabel) pada taraf signifikansi 5\%, yaitu nilai Fhitung sebesar 1,00 sedangkan nilai Ftabel pada dbantar $=5$ dan dbdalam $=185$ adalah 2,34. Maka, H0 diterima dan H1 ditolak yang artinya tidak adanya perbedaan yang signifikan hasil belajar IPA antara kelompok siswa yang dibelajarkan dengan model pembelajaran Word Square berbantuan media gambar dan kelompok siswa yang tidak dibelajarkan dengan model pembelajaran Word Square berbantuan media gambar terhadap hasil belajar IPA kelas V siswa di gugus VII Kecamatan Seririt.

Penelitian ini menggunakan teknik Random Sampling. Pengambilan sampelnya berdasarkan daerah populasi yang telah ditetapkan. Sampel yang diacak adalah kelas V. Dari 6 sekolah dasar yang terdapat di Gugus VII Kecamatan Seririt, hanya akan di ambil dua kelas yang akan dijadikan sebagai sampel. Kelaskelas tersebut diacak dan dipilih dua buah kelas menjadi sampel yang terbagi menjadi dua yaitu kelas eksperimen dan kelas kontrol. Pada penelitian ini teknik random sampling dilakukan dengan undian. Teknik analisis data yang digunakan dalam penelitian ini yaitu uji prasyarat, dan uji hipotesis. Teknik analisis statistik inferensial yang digunakan adalah uji-t. Sebelum melakukan uji-t, terlebih dahulu dilakukan analisis uji prasyarat yang meliputi uji normalitas dan uji homogenitas. Teknik analisis data yang digunakan untuk menguji hipotesis dari penelitian ini adalah menggunakan uji-t independen untuk menguji hasil post-test kelompok eksperimen dan kelompok kontrol (01 dan 02)

\section{Hasil dan Pembahasan}

Data tentang hasil belajar IPA pada ranah kognitif yang diperoleh dari posttest setelah mengadakan 7 kali pertemuan pada masing-masing kelompok siswa yang dibelajarkan menggunakan model pembelajaran Word Square berbantuan media gambar maupun kelompok siswa yang dibelajarkan menggunakan model pembelajaran konvensional. Posttest dilakukan dengan memberikan soal pilihan ganda yang berjumlah 30 soal yang telah divalidasi. Jumlah siswa yang dianalisis data hasil belajar IPA pada kelompok eksperimen adalah 28 orang siswa dan pada kelompok kontrol berjumlah 26 orang siswa. 
Deskripsi hasil penelitian data hasil belajar IPA siswa memaparkan mean, median, modus, varians dan standar deviasi. Hasil deskripsi data dapat dilihat pada Tabel 2.

Tabel 2. Deskripsi Data Hasil Belajar IPA

\begin{tabular}{lcc}
\hline \multicolumn{1}{c}{ Hasil Analisis } & Kelompok Eksperimen & Kelompok kontrol \\
\hline Mean & 19,96 & 15 \\
Median & 20,5 & 14,7 \\
Modus & 21,63 & 14,5 \\
Varians & 17,39 & 14,06 \\
Standar Deviasi & 4,17 & 3,75 \\
Skor Maksimum & 29 & 23 \\
Skor Minimum & 12 & 8 \\
\hline
\end{tabular}

Data hasil belajar IPA yang diperoleh melalui post-test terhadap 28 orang siswa menunjukkan bahwa skor tertinggi adalah 29 dan skor terendah adalah 12. Berdasarkan Tabel 4.2, dapat dideskripsikan nilai dari mean (M), median (Md), modus (Mo), varians, dan standar deviasi (s) dari data hasil belajar IPA kelompok eksperimen, yaitu mean $(M)=19,964$, median $(M d)=20,5$, modus $(M o)=21,63$, varians $\left(s^{2}\right)=$ 17,39 dan standar deviasi $(\mathrm{s})=4,17$.

Mean (M), median (Md), modus (Mo) hasil belajar IPA siswa kelompok eksperimen selanjutnya disajikan ke dalam kurva poligon untuk mendeskripsikan sebaran data hasil belajar IPA pada kelompok eksperimen. Hubungan antara Mean (M), median (Md), dan modus (Mo) dapat digunakan untuk menentukan kemiringan kurva poligon distribusi frekuensi. Data hasil belajar IPA kelompok eksperimen disajikan ke dalam bentuk kurva poligon seperti pada Gambar 1.

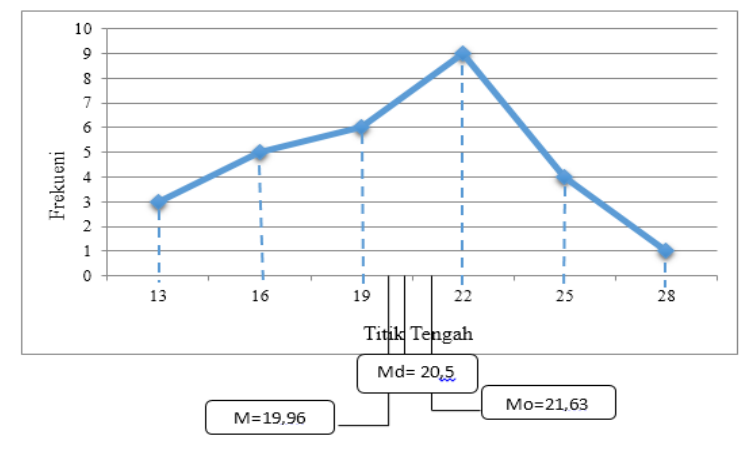

Gambar 1

Kurva Poligon Data Hasil Belajar Kelompok Eksperimen

Berdasarkan kurva poligon data hasil belajar kelompok eksperimen di atas, dapat diketahui bahwa modus lebih besar dari median dan median lebih besar dari mean (Mo $>M d>M)$. Dengan kata lain, kurva di menunjukkan kurva juling negatif. Artinya, sebagian besar skor cenderung tinggi. Kecenderungan skor ini dapat dibuktikan dengan melihat frekuensi relatif pada tabel distribusi frekuensi. Frekuensi relatif skor yang berada di atas rata-rata lebih besar dibandingkan frekuensi relatif skor yang berada di bawah ratarata.Data hasil belajar IPA yang diperoleh melalui post-test terhadap 26 orang siswa menunjukkan bahwa skor tertinggi adalah 23 dan skor terendah adalah 8. Nilai Mean (M), median (Md), modus (Mo) hasil belajar IPA siswa kelompok kontrol selanjutnya disajikan ke dalam kurva poligon. Nilai mean $(M)=15$, median $(\mathrm{Md})=14,7$, modus $(\mathrm{Mo})=14,5$, varians $\left(s^{2}\right)=14,06$ dan standar deviasi $(\mathrm{s})=3,75$. Data hasil belajar IPA kelompok kontrol disajikan ke dalam bentuk kurva poligon seperti pada Gambar 2 . 


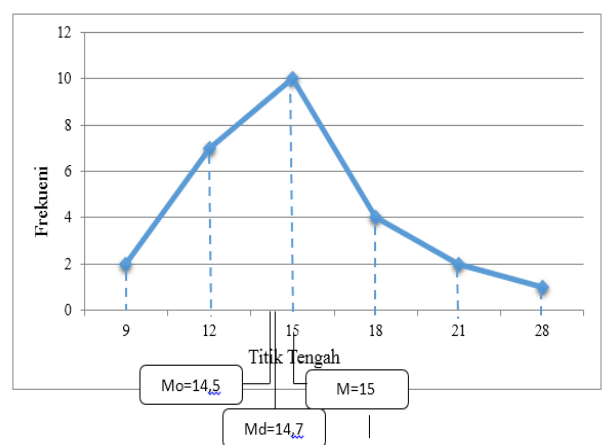

Gambar 2

Kurva Poligon Data Hasil Belajar Kelompok Kontrol

Berdasarkan kurva poligon data hasil belajar kelompok kontrol di atas, dapat diketahui bahwa modus lebih kecil dari mean dan mean lebih kecil dari median $(\mathrm{Mo}<\mathrm{Md}<\mathrm{M})$. Dengan kata lain, kurva di menunjukkan kurva juling positif. Artinya, sebagian besar skor cenderung rendah. Kecenderungan skor ini dapat dibuktikan dengan melihat frekuensi relatif pada tabel distribusi frekuensi. Frekuensi relatif skor yang berada di atas rata-rata lebih kecil dibandingkan frekuensi relatif skor yang berada di bawah ratarata. Uji normalitas sebaran data dilakukan untuk mengetahui apakah data yang diperoleh berdistribusi normal atau tidak. Uji normalitas data dilakukan terhadap data hasil belajar IPA kelompok eksperimen dan kontrol. Berdasarkan analisis data yang dilakukan dengan menggunakan program Microsoft Office Excel 2013 for Windows, dapat disajikan hasil uji normalitas sebaran data hasil belajar IPA kelompok eksperimen dan kontrol pada Tabel 3.

Tabel 3. Rangkuman Hasil Uji Normalitas Sebaran Data

\begin{tabular}{llccc}
\hline No & Kelompok Data Hasil Belajar IPA & $\chi^{2}$ hitung & $\chi^{2}$ tabel & Keterangan \\
\hline 1 & Post-test Eksperimen & 1,403 & 7,815 & Normal \\
\hline 2 & Post-test Kontrol & 1,746 & 7,815 & Normal \\
\hline
\end{tabular}

Kriteria pengujian, jika $\chi_{h i t}^{2}<\chi^{2}{ }_{t a b}$ dengan taraf signifikasi 5\% (dk = jumlah kelas dikurangi parameter, dikurangi 1), maka data berdistribusi normal. Sedangkan, jika $\chi^{2}{ }_{h i t} \geq \chi^{2}$ tab, maka sebaran data tidak berdistribusi normal. Berdasarkan hasil perhitungan degan menggunakan rumus chi-kuadrat, diperoleh $\chi^{2}{ }_{\text {hit }}$ hasil post-test kelompok eksperimen adalah 1,403 dan $\chi^{2}$ tab dengan taraf signifikasi $5 \%$ dan $\mathrm{db}=3$ adalah 7,815. Hal ini berarti, $\chi^{2}$ hit hasil post-test kelompok eksperimen lebih kecil dari $\chi_{t a b}^{2}\left(\chi_{h i t}^{2}<\chi_{t a b}^{2}\right)$, sehingga data hasil post-test kelompok eksperimen berdistribusi normal. Sedangkan, $\chi^{2}$ hit hasil post-test kelompok kontrol adalah 1,746 dan $\chi^{2}$ tab dengan taraf signifikansi $5 \%$ dan $\mathrm{db}=3$ adalah 7,815. Hal ini berarti, $\chi^{2}$ hit hasil post-test kelompok kontrol lebih kecil dari $\chi^{2}$ tab ( $\chi^{2}{ }_{h i t}<\chi_{t a b}^{2}$ ), sehingga data hasil post-test kelompok kontrol berdistribusi normal.

Uji homogenitas varians antar kelompok bertujuan untuk memeriksa kesamaan varians antar kelompok perlakuan. Dalam penelitian ini, uji homogenitas dilakukan terhadap varians pasangan antar kelompok eksperimen dan kontrol. Uji yang digunakan adalah uji-F dengan kriteria data homogen jika $F_{\text {hit }}$

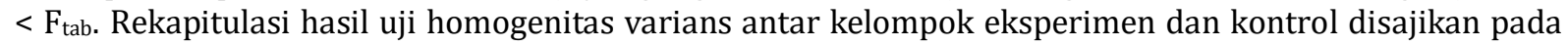
Tabel 4

Tabel 4. Rangkuman Homogenitas Varians antar Kelompok Eksperimen dan Kontrol

\begin{tabular}{lllccc}
\hline & Data & & $F_{\text {hitung }}$ & Ftabel & Status \\
\hline $\begin{array}{l}\text { Post-Test } \\
\text { Kontrol }\end{array}$ & Kelompok & Eksperimen dan Kelompok & 1,237 & 4 & Homogen \\
\hline
\end{tabular}


Berdasarkan tabel di atas, diketahui $\mathrm{F}_{\text {hit }}$ hasil kelompok eksperimen dan kontrol adalah 1,237 sedangkan $\mathrm{F}_{\text {tab }}$ pada $\mathrm{df}_{1}=1, \mathrm{df}_{2}=52$, dan taraf signifikansi $5 \%$ adalah 4 . Hal ini berarti, varians data hasil belajar IPA kelompok eksperimen dan kontrol adalah homogen

Untuk mengetahui pengaruh model pembelajaran Word Square berbantuan media gambar terhadap hasil belajar IPA siswa, dilakukan pengujian terhadap hipotesis nol $\left(\mathrm{H}_{0}\right)$. Jika terbukti bahwa kedua sampel berdistribusi normal dan berasal dari populasi dengan variasi yang homogen, maka dipergunakan analisis uji-t ( $t$-test) dengan taraf signifikansi $5 \%$ dengan rumus polled varians. Kriteria pengujian adalah tolak $\mathrm{H}_{0}$ jika $t_{\text {hit }}>t_{t a b}$, dimana $t_{\text {tab }}$ diperoleh dari tabel distribusi $t$ pada taraf signifikansi $5 \%$ dengan derajat kebebasan $\mathrm{db}=\mathrm{n} 1+\mathrm{n} 2-2$. Rangkuman hasil perhitungan uji-t ditampilkan pada Tabel 5

Tabel 5. Rangkuman Hasil Perhitungan Uji-T

\begin{tabular}{|c|c|c|c|c|c|c|}
\hline Kelompok & $\mathrm{N}$ & $\mathrm{Db}$ & Mean & $s^{2}$ & $t_{\text {hit }}$ & $t_{\text {tab }}$ \\
\hline Eksperimen & 28 & \multirow{2}{*}{52} & 19,96 & 17,39 & \multirow{2}{*}{9,143} & \multirow{2}{*}{2,021} \\
\hline Kontrol & 26 & & 15 & 14,06 & & \\
\hline
\end{tabular}

Berdasarkan tabel analisis di atas, dapat diketahui $t_{\text {hit }}=9,143$ dan $t_{\text {tab }}=2,021$ untuk db $=52$ pada taraf signifikansi 5\%. Berdasarkan kriteria pengujian, $\mathrm{t}_{\text {hit }}>\mathrm{t}_{\text {tab }}$ maka $\mathrm{H}_{0}$ ditolak dan $\mathrm{H}_{1}$ diterima. Artinya, terdapat pengaruh yang signifikan hasil belajar IPA antara siswa kelas V SD 39ng dibelajarkan menggunakan model pembelajaran Word Square berbantuan media gambar dan hasil belajar IPA siswa kelas V SD yang dibelajarkan menggunakan pembelajaran konvensional di Gugus VII Kecamatan Seririt tahun pelajaran 2017/2018 Hasil analisis data hasil belajar menunjukkan bahwa terdapat perbedaan hasil belajar antara siswa yang dibelajarkan dengan model pembelajaran Word Square berbantuan media gambar dan kelompok siswa yang dibelajarkan dengan pembelajaran konvensional. Tinjauan ini didasarkan pada hasil data post-test siswa dan hasil uji-t. Post-test diberikan setelah adanya perlakuan model pembelajaran Word Square berbatuan media gambar. Hasil perhitungan menyatakan bahwa hasil post-test kelas eksperimen lebih besar dari kelas kontrol. Hal ini dibuktikan dari rata-rata skor hasil belajar IPA kelas eksperimen dan kelas kontrol.

Rata-rata skor kelas eksperimen adalah 19,96 berada pada kategori sangat tinggi, sedangkan rata-rata skor kelas kontrol adalah 15 berada pada kategori sedang. Selanjutnya analisis data menggunakan uji-t, diketahui thit $=9,143$ dan tab pada taraf signifikansi $5 \%=2,021$. Hasil perhitungan tersebut menunjukkan bahwa $t_{\text {hitung }}$ lebih besar daripada $t_{\text {tabel }}$ ( $t_{\text {hitung }}>t_{\text {tabel }}$ ) sehingga hasil penelitian adalah signifikan. Hal ini berarti terdapat perbedaan yang signifikan hasil belajar IPA antara siswa yang dibelajarkan dengan model pembelajaran Word Square berbantuan media gambar dan siswa yang dibelajarkan dengan model pembelajaran konvensional pada siswa kelas V SD Gugus VII Kecamatan Seririt Kabupaten Buleleng tahun pelajaran 2017/2018. Adanya perbedaan yang signifikan menunjukkan bahwa penerapan model pembelajaran Word Square berbantuan media gambar berpengaruh pada hasil belajar IPA siswa. Perbedaan hasil belajar IPA antara kelompok siswa yang mengikuti pembelajaran dengan model Word Square berbatuan media gambar dan kelompok siswa yang mengikuti pembelajaran dengan model pembelajaran konvensional. Model pembelajaran Word Square berbantuan media gambar dapat meningkatkan kemampuan siswa dalam mengingat suatu informasi dan siswa juga dapat belajar tanpa rasa jenuh karena proses pembelajaran dikonsep seperti permainan. Dengan begitu pembelajaran terasa menyenangkan bagi siswa. Guru tidak lagi sebagai satu-satunya sumber pembelajaran (teacher centered) tetapi justru siswa yang dituntut untuk dapat menemukan dan memahami konsep baru (student centered). Melalui model pembelajaran Word Square berbatuan media gambar ini siswa dapat meningkatkan hasil belajar siswa. Jadi model pembelajaran Word Square berbatuan media gambar lebih baik diterapkan untuk meningkatkan hasil belajar IPA siswa dibandingkan dengan model pembelajaran konvensioanl.

Temuan yang menunjukkan bahwa skor rata-rata hasil belajar IPA kelas eskperimen cenderung tinggi disebabkan oleh beberapa hal. Pertama, guru lebih mempersiapkan diri untuk mengajar karena adanya peneliti selama proses pembelajaran berlangsung. Dengan guru mempersiapkan diri dapat dibuktikan bahwa dirinya dapat menjadi guru yang professional. Kedua, siswa menjadi semangat dalam mengikuti pembelajaran karena guru menerapkan pembelajaran baru yang menyenagkan sehingga siswa menjadi termotivasi untuk belajar. Dengan demikian hasil belajar IPA semakin meningkat. Ketiga, keterlibatan peneliti selama proses pembelajaran yang membuat suasana kelas menjadi berbeda dari hari-hari biasanya. Dengan adanya peneliti selama proses pembelajaran berlangsung sikap siswa mejadi lebih aktif dan siswa bersemangat untuk mengemukakan pendapatnya serta ingin menunjukkan kemampuanya dalam pembelajaran. Temuan tersebut didukung dengan penjelasan (G. A. Lestari, Negara, \& Ganing, 2017) yang menyatakan hasil belajar siswa yang mengikuti pembelajaran menggunakan Model 
Pembelajaran Word Square berada pada kategori tinggi sehingga model pembelajaran ini bagus untuk meningkatkan hasil belajar IPA siswa.

Hasil penelitian yang diperoleh pada penelitian ini juga sejalan dengan penelitian yang dilakukan oleh Aingsih (2012) yang berjudul Pengaruh Model Pembelajaran Word Square Berbantuan Media Gambar Terhadap Hasil Belajar IPA Kelas IV SD Gugus 1 Kecamatan Pupuan ini menyatakan bahwa terdapat perbedaan yang signifikan hasil belajar IPA antara kelompok yang mengikuti pembelajaran dengan menggunakan model pembelajaran Word Square berbantuan media gambar dan kelompok yang mengikuti pembelajaran konvensional pada siswa kelas IV Semester II SD 1 dan 3 Pajahan Kecamatan Pupuan Kabupaten Tabanan. Hal ini dibuktikan dengan rata-rata kelompok eksperimen $(23,97)$ lebih besar dari rata-rata kelompok kontrol $(16,29)$. Berdasarkan hasil tersebut dapat disimpulkan bahwa nilai rata-rata tes siswa kelas eksperimen lebih besar dibandingkan kelas kontrol dan juga terdapat perbedaan hasil belajar dari kedua kelas tersebut. Temuan lain yaitu hasil penelitian oleh Muriana (2014). Hasil penelitian menunjukan bahwa pembelajaran dengan model Word Square menyebabkan adanya perbedaan yang signifikan pada hasil belajar IPA siswa kelas IV SD Desa Tista. Berikutnya adalah hasil penelitian oleh Sukandheni (2014) menunjukan bahwa penggunaan model pembelajaran Word Square berbasis lingkungan menyebabkan perbedaan yang signifikan hasil belajar IPA siswa kelas V Gugus Budi Utomo Denpasar Timur

Berbeda halnya dalam pembelajaran konvensional yang merupakan pembelajaran yang biasa dilakukan oleh guru. Dalam proses pebelajaran terlihat bahwa guru memberikan materi pelajaran melalui metode ceramah, latihan soal-soal kemudian pemberian tugas pada siswa. Dalam pembelajaran konvensioanal yang menjadi pusat pembelajaran adalah guru, sehingga pandangan siswa hanya tertuju pada guru. Kegiatan pembelajaran tidak diimbangi dengan aktivitas siswa, sehingga siswa terlihat bosan dalam menerima materi yang diajarkan, dan setiap materi yang diberikan oleh guru akan cepat dilupakan oleh siswa. Hal ini sejalan dengan pendapat Rasana (dalamPerdani, Gading, \& Riastini, 2016)menyatakan penyampaian materi dalam pembelajaran konvensional lebih banyak dilakukan melalui metode ceramah secara terus menerus. Artinya penyajian materi sepenuhnya dilakukan oleh guru sebagai sumber informasi atau pembelajaran dikatakan berpusat pada guru (teacher centered). Dalam pembelajaran konvensional siswa hanya berfungsi sebagai penerima informasi dari guru tanpa adanya hubungan timbal balik antara guru dan siswa.

Perbedaan cara pembelajaran antara kelompok siswa yang dibelajarkan menggunakan model pembelajaran Word Square berbantuan media gambar dan kelompok siswa yang dibelajarkan menggunakan model pembelajaran konvensional memberikan dampak yang berbeda terhadap hasil belajar siswa. Penerapan model pembelajaran Word Square berbantuan media gambar dalam pembelajaran memungkinkan siswa untuk tahu manfaat dari materi yang dipelajari bagi kehidupan dan pembelajaran menjadi lebih bermakna, siswa akif dalam pembelajaran, serta dapat menumbuhkan ketelitian siswa. Sesuai pendapat K. T. Lestari (2013) model pembelajaran Word Square merupakan salah satu model yang membutuhkan suatu kejelian dan ketelitian siswa yang dapat merangsang siswa untuk berpikir efektif melalui permainan acak huruf dalam pembelajaran, Siswa akan senang dalam mengkuti kegiatan pembelajaran karena dalam proses pembelajaran dikonsep dalam bentuk permainan untuk menjawab soal yang dibuat oleh guru, dalam menjawab soal inilah menimbulkan nuansa persaingan positif antar siswa karena setiap siswa tentunya menginginkan untuk mendapat jawaban yang tepat dan mendapat skor tertinggi. Sehingga setiap siswa antusias dalam mengerjakan setiap pertanyaan yang yang ada dalam lembaran Word Square. Dengan demikian hasil belajar IPA kelompok siswa yang dibelajarkan menggunakan model pembelajaran Word Square berbantuan media gambar lebih baik dibandingkan dengan kelompok siswa yang dibelajarkan menggunakan model pembelajaran konvensional.

Hambatan yang ditemukan ketika dilakukan penelitian pada kelas eksperimen tidak terlalu berarti. Hanya ada beberapa hambatan kecil seperti masih terdapat beberapa siswa yang suka bercanda dalam mengikuti proses pembelajaran tetapi hal tersebut sudah dapat ditanggulangi oleh guru dengan memberikan perhatian lebih kepada siswa yang bersangkutan. Sementara hambatan di kelas kontrol lebih banyak ditemukan. Hambatan-hambatan tersebut adalah banyak ditemukan siswa yang kurang memperhatikan guru saat menjelaskan materi seperti siswa bermain-main di kelas. Selain itu terdapat pula beberapa siswa yang mengantuk pada saat proses pembelajaran berlangsung.

\section{Simpulan dan Saran}

Berdasarkan rumusan masalah dan pembahasan di atas, dapat disimpulkan bahwa terdapat pengaruh yang signifikan hasil belajar IPA antara siswa kelas V SD yang dibelajarkan menggunakan model pembelajaran Word Square berbantuan media gambar dan hasil belajar IPA siswa kelas V SD yang dibelajarkan menggunakan pembelajaran konvensional di Gugus VII Kecamatan Seririt tahun pelajaran 
2017/2018. Hal ini dapat dilihat berdasarkan hasil pengujian hipotesis dengan menggunakan uji-t diperoleh thitung 9,143 dan ttabel dengan taraf signifikansi 5\% dan db $=52$ adalah 2,021. Ini berarti thitung>ttabel, sehingga H0 ditolak dan $\mathrm{H} 1$ diterima. Artinya model pembelajaran Word Square berbatuan media gambar memiliki pengaruh yang signifikan terhadap hasil belajar V SD di Gugus VII Kecamatan Seririt tahun pelajaran 2017/2018.

Adapun saran yang diajukan berdasarkan hasil penelitian dan pembahasan adalah sebagai berikut. (1) kepada siswa di sekolah dasar, melalui model pembelajaran Word Square agar lebih aktif dan kreatif dalam mengikuti pembelajaran sehingga dapat meningkatkan hasil belajar, (2) kepada guru agar hasil penelitian ini dapat dijadikan acuan dan pengetahuan baru dalam menciptakan suasana pembelajaran yang aktif, inovatif khususnya model pembelajaran kooperatif tipe Word Square berbantuan media gambar sehingga dapat mengimplementasikannya di dalam kelas untuk meningkatkan kualitas proses pembelajaran dan hasil pembelajaran IPA, (3) kepada Kepala Sekolah agar hasil penelitian ini dapat dijadikan informasi yang berharga dalam proses pembelajaran untuk meningkatkan hasil belajar IPA khususnya, serta untuk meningkatkan kualitas dan hasil belajar siswa pada umumnya, dan (4) kepada peneliti lain agar memperhatikan kendala yang dialami dalam pelaksanaan model pembelajaran Word Square khususnya dalam pembelajaran IPA untuk penyempurnaan penelitian yang akan dilaksanakan.

\section{Daftar Rujukan}

Aingsih, N. N. (2012). Pengaruh Model Pembelajaran Word Square Berbantuan Media Gambar Terhadap Hasil Belajar IPA Kelas IV SD Gugus 1 Kecamatan Pupuan. E-Journal PGSD Pendidikan Ganesha Mimbar PGSD, 1(1).

Dimyati;Mudjiono. (2009). Belajar dan Pembelajaran. Jakarta: Rineka Cipta.

Djamarah, \& Zain. (2002). Belajar dan Pembelajaran. Jakarta: PT Rineka Cipta.

Hasni, M. Y. H. (2017). Pengaruh Model Pembelajaran Kooperatif Tipe Word Square Berbasis Lari Estafet Terhadap Hasil Belajar. Jurnal Pendidikan Fisika, 5(1), 39-44.

Hermandannu, B. (2018). Penerapan Model Pembelajaran Word Square untuk Menigkatkan Hasil Belajar IPS Siswa Kelas 3 SDN 2 Slempit Kedamean Gresik. JPGSD, 6(12), 2201-2210.

Kurniasari, M. N. P. (2013). Pengaruh Model Pembelajaran Word Square Berbantuan Media Gambar Terhadap Hasil Belajar IPS Siswa Kelas IV SD Gugus V Kecamatan Tegallalang. E-Journal PGSD Pendidikan Ganesha Mimbar PGSD, 1(1).

Lestari, G. A., Negara, I. G. A. O., \& Ganing, N. N. (2017). Pengaruh Model Pembelajaran Word Square Berbantuan Media Lingkungan terhadap Penguasaan Kompetensi Pengetahuan IPA. . E-Journal PGSD Universitas Pendidikan Ganesha Mimbar PGSD, 5(2).

Lestari, K. T. (2013). Pengaruh Model Pembelajaran Word SquareTerhadap Hasil Belajar IPS Kelas III SD. E-Journal PGSD Pendidikan Ganesha Mimbar PGSD, 1(1).

Muriana, D. G. A. (2014). Pengaruh Model Pembelajaran Word Square Terhadap Hasil Belajar IPA Pada Siswa Kelas IV Semester II Tahun Pelajaran 2013/2014 Di SD Desa Tista Tahun Pelajaran 2013/2014. E-Journal PGSD Pendidikan Ganesha Mimbar PGSD, 2(1).

Perdani, I. G. A. M., Gading, K., \& Riastini, P. N. (2016). Pengaruh Model Pembelajaran Word Square terhadap Hasil Belajar IPA pada Siswa Bermotivasi Belajar Berbeda di Kelas IV SD. E-Journal PGSD Pendidikan Ganesha Mimbar PGSD, 4(1).

Pindo, H., \& Simbolon, R. (2018). Meningkatkan Hasil Belajar Siswa dengan Alat Peraga pada Mata Pelajaran IPA Kelas IV SDN Nomor 14 Simbolon Purba. SEJ (School Education Journal) PGSD FIP UNIMED, 8(2), 2-8.

Putri, A. D. (2017). Pengaruh Model Pembelajaran Word Square terhadap Kemampuan Menjelaskan Energi Alternatif dan Cara Penggunaannya Semester 2 Kelas IV SDN Burengan 2 Kota Kediri TA 2015/2016. Simki-Pedagogia, 1(11), 2-8.

Rooijakkers, A. (1991). Mengajar Dengan Sukses: Petunjuk Untuk Merencanakan dan Menyampaikan Pengajaran. Jakarta: Gramedia Widiasarana.

Sukandheni, L. P., Suadnyana, I. N., \& Putra, K. N. S. (2014). Pengaruh Penerapan Model Pembelajaran Kooperatif Tipe Word Square Berbasis Lingkungan Terhadap Hasil Belajar Ipa Kelas V Gugus Budi 
Utomo Denpasar Timur. E-Journal PGSD Pendidikan Ganesha Mimbar PGSD, 2(1).

Swapranata, A. A. N. A., Riastini, P. N., \& Japa, I. G. N. (2016). Penerapan Model Pembelajaran Word Square untuk Meningkatkan Hasil Belajar IPA Siswa KELAS V Semester Genap. E-Journal PGSD Pendidikan Ganesha Mimbar PGSD, 4(1), 1-11.

Trianto. (2012). Model Pembelajaran Terpadu. Jakarta: PT Budi Aksara.

Widiartini, S. (2014). Pengaruh Model Pembelajaran Word Square Terhadap Keterampilan Menyimak Cerita Kelas V SD Gugus IX Kecamatan Buleleng. E-Journal PGSD Pendidikan Ganesha Mimbar PGSD, 2. 